\title{
Peningkatan Pengetahuan Masyarakat KPM-PKH tentang Penyakit Diare dan Kesehatan Lingkungan di Kecamatan Woyla Kabupaten Aceh Barat
}

\author{
Azwar ${ }^{1}$, Arif Iskandar ${ }^{2}$, Ishalyadi ${ }^{3}$, Iwan Doa Sempena ${ }^{4}$ \\ 1,2,3Jurusan Ilmu Kesehatan Masyarakat, Universitas Teuku Umar \\ 4Prodi Ilmu Komunikasi, Universitas Teuku Umar \\ Email: azwar@utu.ac.id \\ Email: arifiskandar@utu.ac.id \\ Email: ishalyadi@utu.ac.id \\ Email: iwan_sempena@yahoo.com \\ Coresponding author : Azwar, e-mail : azwar@utu.ac.id
}

\begin{abstract}
Abstark
Diarrheal disease is still one of the main causes of pain and death in the world. Diarrhea has attacked all age groups and severe illness with high mortality obtained in infants and children. Poor environmental conditions are one of the factors increasing the incidence of diarrhea. To overcome environmental problems, one thing that can be done is to increase public awareness and knowledge with indicators of public health through dedication. The purpose of this service is to increase public knowledge about preventing diarrheal diseases and maintaining environmental health. This community service uses lecture, audio-visual and demonstration methods. The results of this dedication can be illustrated by the danger that there is an increase in people's knowledge and insight in tackling and preventing diarrheal diseases as well as increasing public awareness about the importance of protecting the environment in order to remain good and healthy.
\end{abstract}

Keywords: Diarrhea, Knowledge, Environmental Health.

\begin{abstract}
Abstark
Penyakit diare masih menjadi salah satu penyebab utama terjadinya kematian di dunia. Diare dapat menyerang semua kelompok usia dan salah satu penyakit berat dengan kematian yang tinggi terutama pada kelompok bayi dan anak-anak. Kondisi lingkungan yang buruk merupakan salah satu faktor yang dapat menyebabkan meningkatnya kasus diare pada masayarakat. Untuk mengatasi permasalaan lingkungan yang buruk, seperti perilaku masyarakat yang membuang sampah tidak pada tempatnya. Maka salah satu upaya yang dapat dilakukan adalah dengan meningkatkan pengetahuan dan kesadaran masyarakat melalui kegiatan pengabdian sehingga akan dapat berpengaruh pada peningkatan sikap yang posistif dan tindakan yang baik untuk menjaga lingkungan yang kondusif agar kasus diare dapat dicegah. Tujuan pengabdian ini adalah untuk meningkatkan pengetahuan masyarakat tentang pencegahan penyakit diare dan menjaga kesehatan lingkungan. Pengabdian masyarakat ini menggunakan metode ceramah, audio visual dan demonstrasi. Hasil dari pengabdian ini dapat digambarkan bahwa terdapat peningkatan pengetahuan dan wawasan masyarakat dalam mencegah dan menanggulangi terjadinya penyakit diare. Pengabdian ini juga dapat
\end{abstract}


meningkatkan pengetahuan serta kesadaran masyarakat tentang pentingnya menjaga lingkungan yang bersih dan sehat sehingga menurunkan kasus penyakit diare.

Kata Kunci : Diare, Pengetahuan, Kesehatan lingkungan.

\section{PENDAHULUAN}

\section{Masalah \\ kesehatan} merupakan salah masalah yang cukup kompleks dan saling berkaitan dengan masalah lain di luar kesehatan itu sendiri. Pemecahan masalah kesehatan masyarakat juga tidak dapat di kaji dari bidang kesehatannya saja, namun juga harus di kaji dari seluruh segi kesehatan dan pengaruhnya terhadap sakit dan sehat serta kesehatan tersebut.

Pada pembangunan

kesehatan, lingkungan merupakan indikator yang sangat berpengaruh terhadap kesehatan. Lingkungan yang diharapkan adalah lingkungan yang bersih dan kondusif sehingga terwujudnya keadaan sehat yaitu lingkungan yang bebas dari pencemaran, tersedianya air bersih, sanitasi lingkungan yang sehat, perencanaan kawasan yang berlandaskan kesehatan, perumahan dan pemukiman yang sehat serta terwujudnya kehidupan masyarakat, yang saling tolong menolong dalam memelihara nilainilai budaya bangsa (Notoatmodjo. S, 2003).
Lingkungan memiliki dua unsur pokok yang sangat erat terkait satu sama lain yaitu unsur sosial dan fisik. Lingkungan sosial contohnya ketidakadilan sosial yang bisa menyebabkan kemiskinan yang berdampak terhadap status kesehatan masyarakat yang mengakibatkan timbulnya penyakit berbasis lingkungan. Pada teori Hendrik L. Blum ada empat faktor yang mempengaruhi status derajat kesehatan masyarakat atau individu yaitu lingkungan, perilaku, fasilitas kesehatan dan keturunan. Lingkungan memiliki pengaruh yang dan peranan terbesar dalam peningkatan kesehatan diikuti perilaku, fasilitas kesehatan dan keturunan (Notoatmodjo. S, 2003).

Lingkungan fisik dapat mempunyai hubungan langsung dengan kesehatan dan perilaku seperti polusi air akibat pembuangan limbah pabrik ke badan air atau ke tempat yang tidak semestinya yang dapat menimbulkan bermacam-macam penyakit seperti ispa, diare, demam berdarah dan lainnya. Selain itu, hubungan kondisi lingkungan fisik 
juga dipengaruhi oleh kebiasaan, adat istiadat, kepercayaan, pendidikan sosial ekonomi, dan perilaku-perilaku lain yang melekat pada masyarakat yang berinteraksi pada lingkungan tersebut(Ramja. M, 2000)

Penyakit diare sampai saat ini masih merupakan salah satu penyebab utama kesakitan dan kematian. Hampir seluruh daerah geografis dunia dan semua kelompok usia diserang diare, tetapi penyakit berat dengan kematian yang tinggi terutama didapatkan pada bayi dan anak-anak. Di negara Amerika Utara anak-anak menderita diare lebih dari 12 kali pertahun (Pitona, A.J., Dasuki, D., Ismail, 2006). Penyakit diare menyebabkan kematian sebesar 15$34 \%$ dari semua kematian, kurang lebih 300 kematian per tahun (Zubir, 2005). Lebih dari 5.000 balita meninggal akibat penyakit ini, penyabab utamanya adalah buruknya kesehatan lingkungan. Penyakit diare merupakan penyakit yang sangat berhubungan dengan lingkungan (Bartram. J, 2008).

Kematian akibat diare di Indonesia masih sangat tinggi, dimana saat ini menduduki rangking keenam dengan angka kejadian sekitar 6 juta bayi yang mati pertahunnya. Kematian anak dan balita disebabkan oleh penyakit diare, bahkan untuk mengdiagnosis diare, maka pemeriksaan antigen secara langsung dari tinja mempunyai nilai sensifitas mencapai (70-90\%) (Efra, 2013).

Penyakit diare merupakan salah satu penyakit yang menyumbang angka kematian di Indonesia yang sebabkan oleh infekti rotavirus. Kasus penyakit diare diperkirakan terjadi sebanyak 40 juta setiap tahun dengan jumlah kematian $200.000 \quad-400.000$ balita (Subagyo, B., Santoso, 2012).

Penyakit diare sering menyerang bayi dan balita, bila tidak diatasi lebih lanjut akan menyebabkan dehidrasi yang mengakibatkan kematian. Salah satu faktor risiko adalah faktor lingkungan yang meliputi sarana air bersih ( $\mathrm{SAB})$, sanitasi lingkungan, jamban, dan kondisi rumah. Data terakhir menunjukkan bahwa kualitas air minum yang buruk menyebabkan 300 kasus diare per 1000 penduduk. Sanitasi yang buruk dituding sebagai penyebab banyaknya kontaminasi bakteri e.coli dalam air bersih yang dikonsumsi masyarakat. Kontaminasi bakteri e.coli terjadi pada air tanah yang banyak disedot penduduk, dan sungai yang menjadi sumber air baku di PDAM pun tercemar bakteri ini sehingga mengakibatkan masalah kesehatan (Wiku A, 2007). 
Kondisi lingkungan yang buruk adalah salah satu faktor meningkatnya kejadian diare karena status kesehatan suatu lingkungan yang mencakup perumahan, pembuangan kotoran, dan penyediaan air bersih. Hal ini dapat menyebabkan masalah kesehatan lingkungan yang besar karena dapat menyebabkan mewabahnya penyakit diare dan mempengaruhi kondisi kesehatan masyarakat (Fiesta O.S. Surya D. \& Irnawati M, 2012).

Untuk mengatasi masalah lingkungan, salah satu hal yang dapat dilakukan adalah meningkatkan kesadaran dan pengetahuan masyarakat melalui indikator kesehatan masyarakat agar dapat mengubah kebiasaan buruk yang berdampak tidak baik bagi kesehatan individual maupun kelompok.

Pengabdian masyarakat ini bertujuan untuk meningkatkan pengetahuan masyarakat tentang menjaga lingkungan, mengetahui bahaya dan mencegah penyakit diare, melindungi keluarga dari penularan penyakit diare serta menjaga lingkungan agar tetap sehat dan bersih.

Adanya

peningkatan

pengetahuan tersebut dapat menambah wawasan terkait kesehatan lingkungan dan menyadarkan masyarakat tentang pentingnya menjaga lingkungan serta mencegah dan melindungi diri sendiri dan keluarga dari penyakit diare, menerapkan perilaku hidup bersih dan sehat yang menguntungkan bagi kesehatan masyarakat maupun lingkungan.

Sasaran dalam pengabdian masyarakat ini adalah masyarakat keluarga penerima manfaat program keluarga harapan (KPMPKH) Kementerian Sosial RI di Gampong Padang Jawa Kecamatan Woyla Kabupaten Aceh Barat dengan jumlah peserta 38 orang. Kondisi kesehatan lingkungan di Desa Padang Jawa masih sangat rendah.

Hal ini dapat dilihat dari perilaku masyarakat dalam memperlakukan lingkungannya. Masih terdapat masyarakat yang membuang sampah tidak pada tempatnya, sehingga dapat merusak pada kualitas air dan udara. Juga terdapat masyarakat yang memelihara hewan dan membuat kadang peliharaan yang sangat berdekatan dengan rumah. Perilaku tersebut dapat meningkatkan penyakit diare dan menurukan kualitas lingkungan.

Perilaku tidak sehat masyarakat dapat disebakan oleh kurangnya pengetahuan masyarakat terhadapat suatu permasalahan kesehatan. Sehingga diperlukan upaya peningkatan 
pengetahuan yang dapat mengubah persepsi dan meningkatkan kesadaran masyarakat dalam mengelola lingkungannya yang sehat yang dapat mempengaruhi pada penurunan angka kesakita diare. Kegiatan ini dilaksanakan pada tanggal 18 Januari 2020.

\section{METODE PELAKSANAAN}

\section{Dalam}

pelaksanaan

pengabdian masyarakat menggunakan beberapa metode diantaranya (1) metode ceramah. Metode ini digunakan untuk menyampaikan informasi dan materi-materi tentang bahaya dan cara pencegahan penyakit diare serta melindungi dan menjaga diri sendiri, masyarakat dan lingkungan dari penularan penyakit. Metode ini juga memanfaatkan infokus dan laptop untuk memaparkan materi yang akan disampaikan yang tertulis di powerpoint dan dilengkapi juga dengan gambargambar yang berkaitan dengan penyakit diare dan kesehatan lingkungan.(2)Menggunakan audio visual. Metode ini digunakan untuk menanyangkan video dan film-film edukasi yang berkaitan dengan penyakit diare dan kesehatan lingkungan dengan memanfaat laptop, infokus dan speaker (pengeras suara).(3)metode demontrasi. Metode ini digunakan untuk memberikan pemahaman secara aplikatif kepada masyarakat. Mereka dapat secara langsung melakukan praktek untuk menjaga diri sendiri dan lingkungan seperti praktek membuang sampah pada tempat dan mencuci tangan pakai sabun. Demonstrasi ini dilakukan oleh tim pengabdi, masyarakat dan bantuan beberapa mahasiswa yang terlibat dalam kegiatan pengabdian masyarakat ini.

\section{HASIL DAN PEMBAHASAN}

Pengabdian masyarakat ini menunjukkan hasil yang sangat baik. Kegiatan ini dilaksanakan di balai desa atau gampong Padang Jawa Kecamatan Woyla Kabupaten Aceh Barat. Kegiatan ini dilaksanakan sejak pagi sampai dengan siang hari yang di isi oleh masing-masing narasumber dengan materi yang berbeda.

Materi pertama di sampaikan oleh Azwar dan Arif Iskandar yang membahas tentang kesehatan lingkungan. Materi ini lebih menitikberatkan pada perilaku masyarakat dalam menjaga keseimbangan ekologi yang dinamis antara manusia dan lingkungan sehingga terhindar dari penularan penyakit terutama diare. Menurut kementrian kesehatan (2006) ruang lingkup kesehatan lingkungan terbagi menjadi empat yaitu (1)penyediaan air bersih. Dalam materi ini masyarakat diharapkan 
dapat memperoleh air bersih dan menggunakan air bersih dalam kehidupannya sehari-hari. Persediaan air bersih yang terbatas memudahkan timbulnya penyakit dimasyarakat. Volume rata-rata kebutuhan air setiap individu perhari berkisar antara 150-200 liter atau 35-40 galon Budiman Chandra, 2006 dalam (Arnita, 2013). Kebutuhan air tesebut bervariasi dan tergantung pada keadaan iklim, standar kehidupan dan kebiasaan masyarakat. (2) Kepemilikan Jamban. Dalam materi ini diharapkan dapat meningkatkan tingkat pengetahuan masyarakat tentang pentingnya kepemilikan jamban. Kepemilikan tempat pembuangan tinja merupakan salah satu fasilitas yang harus ada dalam rumah yang sehat. Jamban yang yang di miliki oleh masyarakat haruslah jamban yang sehat dan memenuhi standar kesehatan. Jamban yang lebih dikenal dengan WC atau kakus menjadi sumber penyebaran penyakit baik secara langsung maupun tidak langsung bila tidak memenuhi syarat kesehatan. (3) Pengelolaan sampah. Sampah erat kaitannya dengan kesehatan masyarakat, karena dari sampah-sampah tersebut akan hidup berbagai mikroorganisme penyebab penyakit (bakteri phatogen), bahan berbahaya dan beracun dan juga binatang serangga sebagai pemindah atau penyebar penyakit. Selain itu sampah yang tidak disimpan dengan baik dapat menjadi tempat bersarangnya vektor penyakit seperti tikus dan lalat. Vektor ini dapat menyebabkan penyebaran penyakit pada manusia, selain itu sampah yang tidak disimpan dengan baik tidak menarik untuk dilihat. Oleh karena itu, sampah harus dikelola dengan baik sehingga tidak mengganggu dan mengancam kesehatan masyarakat (Ricki M. Mulia, 2005) dalam (Rizkiyanto, 2015). Ruang lingkup kesehatan lingkungan yang ke empat (4) adalah sarana pembuangan limbah. Dalam materi ini diharapkan dapat meningkatkan pengetahuan masyarakat bagaimana masyarakat dapat mengelola dan menyediakan sarana pembuangan air limbah rumah tangga. Air limbah meliputi semua air kotoran yang berasal dari perumahan (kamar mandi, kamar cuci, juga dapur). Apabila masyarakat tidak menyediakan sarana pembuangan air limbah maka akan menimbulkan pencemaran lingkungan sehingga berdampak buruk terhadap kesehatan masyarakat. Menurut Kementerian Kesehatan (2006) untuk mencegah atau mengurangi akibat-akibat buruk tersebut diperlukan kondisi, persyaratan dan upaya-upaya sedemikian rupa 
terhadap air limbah tersebut. Masyarakat dapat menyediakan septi tank yang memenuhi syarat. Saluran air limbah harus kedap air, bersih dan dilengkapi penutup dengan bak kontrol setiap jarak 5 meter.

Materi selanjutnya disampaikan oleh Ishalyadi yang membahas tentang penyakit diare. Materi ini diharapkan dapat meningkatkan pengetahuan masyarakat tentang definisi, penyebab, penularan dan cara pencegahan dari penyakit tersebut. Materi-materi yang telah disampaikan dapat di terima dan di pahami oleh masyarakat. Tingkat pengetahuan masyarakat semakin baik dan meningkat. Mereka lebih mengetahui penyebab terjadinya penyakit diare dan pencegahannya serta dapat menerapkan perilaku hidup bersih dan sehat yang dapat meningkatkan derajat kesehatan masyarakat dan lingkungan.

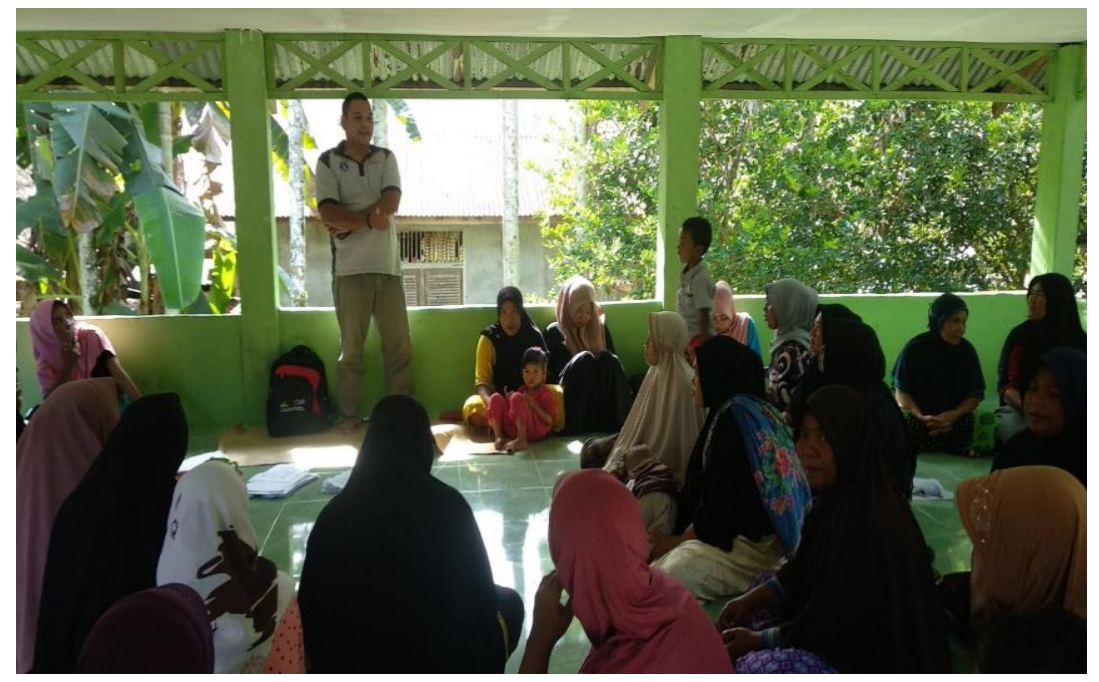

Gambar 1: Penyampaian materi penyuluhan

Peningkatan pengetahuan masyarakat melalui metode ceramah dan presentasi menunjukkan hasil yang sangat baik. Masyarakat antusias mendengarkan materi-materi yang disampaikan hal ini dapat dilihat dari aktifnya masyarakat pada sesi tanya jawab, mereka banyak memberikan pertanyaan, pendapat dan pengalaman yang pernah mereka lakukan dalam mencegah dan menanggulangi penyakit diare dan menjaga kesehatan lingkungan.

Kehadiran peserta yang berasal dari unsur masyarakat keluarga penerima manfaat program keluarga harapan (KPM$\mathrm{PKH}$ ) juga sangat baik. Dalam 
pelaksanaan kegiatan ini menargetkan peserta sebanyak 38 orang, maka dalam pelaksanaannya tingkat kehadiran mencapai 100\%.

Perkembangan penyakit diare sangat erat kaitannya dengan perilaku manusia baik dalam menjaga kesehatan individu maupun dalam menjaga lingkungan agar tetap sehat. Tranmisi penyakit penularan penyakit diare yang terjadi secara fecal oral yaitu melalui tangan, air, makanan dan minuman dapat diputuskan dengan menjaga lingkungan dengan baik, perilaku dan peningkatan pengetahuan masyarakatnya (Soemirat, 2014)

Menurut Briggs dalam (Kholid. Ahmad, 2012) bahwa media sosialisasi atau pembelajar dalam meningkatkan pengetahuan adalah sarana fisik untuk menyampaikan isi/materi seperti : buku, video dan sebagainya. Media ini juga diartikan sebagai sarana komunikasi dalam bentuk cetak maupun pandang-dengar, termasuk teknologi perangkat keras yang dapat menyalurkan pesan yang dapat merangsang pikiran, perasaan maupun kemauan audience sehingga dapat mendorong terciptanya proses belajar pada diri audience (Kholid. Ahmad, 2012).

Audio visual merupakan salah satu media pembelajaran dalam meningkatkan pengetahuan. Media audio visual adalah jenis media yang digunakan dalam kegiatan pembelajaran dengan melibatkan pendengaran dan penglihatan sekaligus dalam satu proses atau kegiatan. Pesan dan informasi yang dapat disalurkan melalui media ini dapat berupa pesan verbal dan nonverbal yang mengandalkan baik penglihatan maupun pendengaran. Beberapa contoh media audio visual adalah film, video, program TV dan lain-lain (Ekawati. Heny, 2017).

Menggunakan audio visual di dalam pengabdian masyarakat ini menunjukkan hasil yang sangat efektif dalam meningkatkan pengetahuan masyarakat yang berhubungan dengan penyakit diare dan kesehatan lingkungan. Masyarakat dapat dengan serius mengikuti video yang dipresentasikan dan mampu memahami dengan baik materi edukasi yang terkandung video tersebut. Hal ini dapat ditunjukkan dari kemampuan masyarakat untuk menceritakan kembali materi-materi yang mereka dapatkan dan membandingkan dengan pengalaman yang telah dilakukan selama ini yang berkaitan dengan penyakit diare.

Meningkatnya pengetahuan masyarakat merupakan target utama dalam pengabdian masyarakat ini. Pengetahuan merupakan faktor dominan yang sangat penting dalam terbentuknya 
tindakan seseorang, sebab dari hasil penelitian ternyata perilaku yang didasari oleh pengetahuan akan lebih baik daripada perilaku yang tidak didasari oleh pengetahuan

(Notoatmodjo. S, 2012).

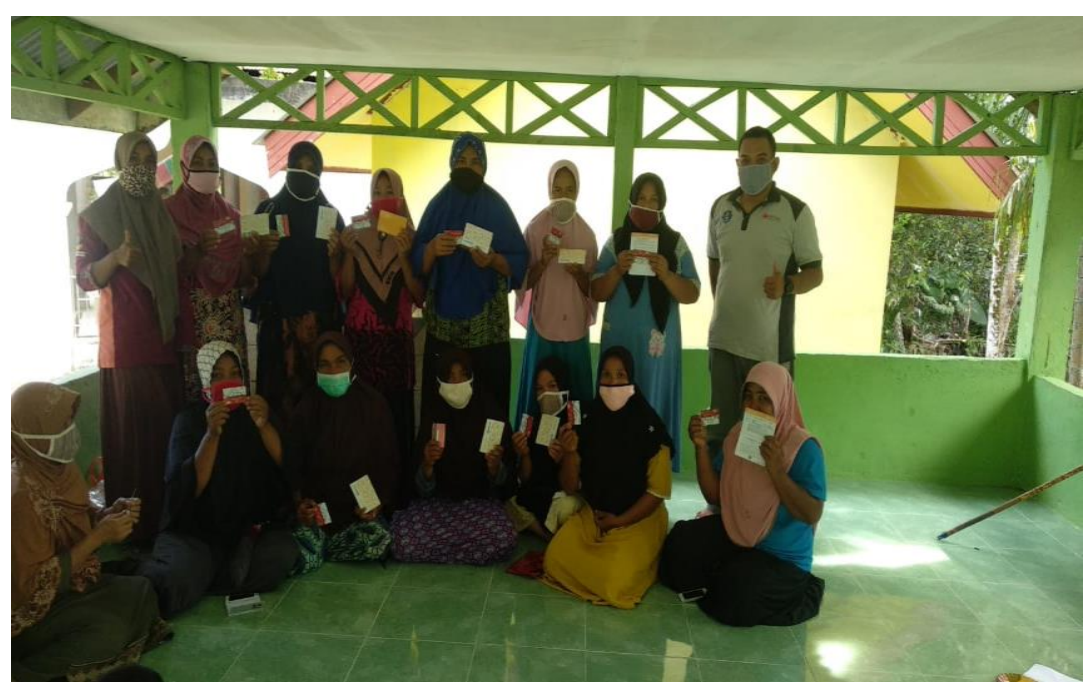

Gambar 2: Foto bersama peserta

Salah satu indikator untuk melihat perubahan perilaku dapat ditunjukkan dari kemampuan untuk menggunakan materi yang telah dipelajari pada situasi atau kondisi real (sebenarnya) atau disebut juga Application. Metode demontrasi yang digunakan di dalam pengabdian masyarakat ini, merupakan metode untuk memberikan pemahaman secara aplikatif kepada masyarakat. Ilmu pengetahuan dan informasiinformasi yang berkaitan dengan penyakit diare dan kesehatan lingkungan yang telah disampaikan dan dipelajari oleh masyarakat dapat ditunjukkan kembali dan diaplikasikan secara bersama-sama. Masyarakat mampu mendemontrasikan bagaimana menjaga lingkungan dengan baik, seperti membuang sampah pada tempatnya, mencuci tangan menggunakan sabun, menutup makanan serta mengkomsumsi air minum yang bersih dan sehat.

\section{PENUTUP}

Kegiatan

masyarakat ini mampu meningkatkan pengetahuan masyarakat. Peserta telah mampu menjelaskan tentang penanggulangi dan mencegah terjadinya penyakit diare dan telah dapat menyadarkan masyarakat tentang pentingnya menjaga lingkungan agar tetap baik dan sehat. Masyarakat juga telah mampu mempraktekkan menjaga 
kebersihan diri dan lingkungan serta berperilaku hidup bersih dan sehat. Selain itu, tingkat kehadiran peserta juga sangat baik yaitu mencapai $100 \%$.

Diharapkan

kepada

masyarakat untuk terus meningkatkan pengetahuannya dengan sering mengikuti pelatihan dan seminar maupun mencari informasi melalui media lainya seperti buku, media cetak dan media elektronik dan kepada pihak lain agar terus melakukan pengabdian untuk meningkatkan pengetahun masyarakat melalui metode yang telah dilakukan maupun metode lain yang akan dikembangkan.

\section{DAFTAR PUSTAKA}

Arnita (2013) Gambaran Sanitasi Lingkungan Di Dususn Bassiu Desa Gunturu Kecamatan Herlang Kabupaten Batu Kumba.Makasar. Uin Alauddin Makasar. Available at: http:/ / repositori.uinalauddin.ac.id.

Bartram. J (2008) Sanitarion is vital for human health.

Efra (2013) 'hubungan kasus diare dengan faktor sosial ekonomi dan perilaku', Bagian ilmu kesehatan masyarakat, 1(2).

Ekawati. Heny (2017) 'Pengaruh Penyuluhan Dengan Audio Visual Terhadap Pengetahuan
Ibu Hamil Tentang ASI Ekskluisf Di Desa Sidobinangun Kecamatan Deket Kabupaten Lamongan', 3(3).

Fiesta O.S. Surya D. \& Irnawati M (2012) Hubungan kondisi lingkungan perumahan dengan kejadian diare di desa sialang buah kecamatan teluk mengkudu kabupaten serdang bedagai tahun 2012.

Kholid. Ahmad (2012) Promosi Kesehatan Dengan Pendekatan Teori Perilaku, Media, dan Aplikasinya. Jakarta: Rajawali Pers.

Notoatmodjo. S (2003) Ilmu Kesehatan Masyarakat, PrinsipPrinsip Dasar. Jakarta: Rineka Cipta.

Notoatmodjo. S (2012) Promosi Kesehatan dan Perilaku Kesehatan. Jakarta: Rineka Cipta.

Pitona, A.J., Dasuki, D., Ismail, D. (2006) 'Penatalaksanaan diare di rumah pada Balita', Berita Kedokteran masyarakat, 22(1), pp. 7-14.

Ramja. M (2000) 'Protozoa parasit penyebab diare', Majalah Kedokteran Sriwijaya, 32(2), pp. 19-22.

Rizkiyanto (2015) Pengaruh Ketersediaansarana Sanitasi Dasar Dan Status Rawan Banjir Terhadap Kejadian Diare.Semarang. Universitas 
Negri Semarang. Available at: http:/ / ejournal.unesa.ac.id.

Soemirat, J. (2014) Kesehatan Lingkungan. 9th edn. Yogyakarta: UGM Press.

Subagyo, B., Santoso, N. B. (2012) Diare akut, Buku ajar Gastroenterologi-Hepatologi. Ikatan Dokter Anak Indobesia.

Wiku A (2007) 'Faktor risiko diare pada bayi dan balita di indonesia: systematic review penelitian akademik bidang kesehatan masyarakat', Makara Kesehatan, 11(1).

Zubir (2005) Faktor-faktor resiko kejadian diare akut pacda anak 0-35 bulan (Batita) di Kabupaten Bantul. Universitas Gadjah Mada. 